\title{
Determinants of Local Government Performance in Indonesia
}

\author{
Dyah Setyaningrum ${ }^{1 *}$, Dwi Martani ${ }^{1}$ \\ ${ }^{1}$ Faculty of Economics and Business, Universitas Indonesia, Depok 16424, Indonesia \\ *dyah.setyaningrum1978@gmail.com
}

\begin{abstract}
The purpose of this study is to analyze the determinants of the performance of local governments in Indonesia. We hypothesize that organizational commitment, management incentives, monitoring, legitimacy, and institutional incentives have positive effects on local government performance. Organizational commitment is measured by follow-up of all audit recommendations and the number of audit findings, while intergovernmental revenue and proportion of non-routine expenditure is used to measure management incentives. Monitoring is measured by political competition and legislature size. Number of voters is used to measure size, while size and wealth of local government is used as the proxy for institutional incentives. Unit analysis of this study is local governments in Indonesia from 2009-2012. The results show that follow-up of audit recommendations, level of dependency, proportion of non-routine expenditure, number of legislature members, number of voters and local government wealth have positive effects on the performance of local governments. Based on these results, local governments should increase their commitment to follow-up of all audit recommendations and increase their proportion of nonroutine expenditure and own-source revenue in order to improve performance. The legislative board can contribute to improved performance by performing effective monitoring.
\end{abstract}

Keywords: Institutional Incentives, Legitimacy, Local Government Performance, Management Incentive, Monitoring, Organizational Commitment

\section{INTRODUCTION}

Local governments arrange and manage their own affairs according to the autonomy principle. Autonomy requires local governments to account for the resources under their stewardship; thus, accountability becomes a crucial issue. Performance measurement is used to measure the accountability of public institutions in terms of use of resources, innovation, and public service quality ${ }^{1}$.

There are several studies related to the determinants of local government performance in Indonesia, especially in terms of the association between local government characteristics and financial performance ${ }^{2,3,4}$. Previous studies have found that the size of local government, local government wealth, and level of dependency on central government have positive effects on performance. In contrast, level of local government expenditure and audit findings have negative effects on local government performance ${ }^{3}$. Another study takes into account the monitoring role, which consists of functional and legislative oversight of local government performance ${ }^{4}$. It is found that local governments led by leaders with entrepreneurial backgrounds perform better than those led by non-entrepreneurs. Entrepreneurial background is believed to have a positive impact in restructuring management style and bureaucracy in government, enabling local government performance to improve. Legislative oversight also has a positive effect on local government performance ${ }^{4}$. Other studies have also confirmed that legislature size is one of the factors affecting local government performance ${ }^{5,6}$.

The purpose of this study is to analyze the determinants of local government performance measurement in Indonesia. Five determinants of performance measurement are identified: (1) organizational commitment; (2) management incentives; (3) monitoring; (4) legitimacy, and (5) institutional incentives. This study offers important contributions for central and local government as it provides input regarding factors that can improve local government performance. Furthermore, descriptive analysis of local government performance scores in Indonesia from 2009 - 2012 are also presented, providing a comprehensive picture and trend information.

\section{LITERATURE REVIEW AND HYPOTHESIS DEVELOPMENT}

Local government performance should be measured and evaluated continuously as a part of local government public accountability. Performance measurement is a tool used to record and assess activity implementation based on the achievement of goals and strategies. Public sector performance measurement will: 1) help to improve local government performance; 2) assist in the allocation of resources and decision-making; and 3) create accountability and improve institutional communication ${ }^{7}$. 
To achieve the requirements of performance improvements in the public sector, the government of Indonesia needs to undertake reforms that focus on performance achievement. The emphasis should be designed to focus on what is being achieved and produced (outcomes and outputs) as well as to improve transparency and accountability in the public sector. Performance management is needed to establish accountability mechanisms that include performance indicators, performance targets, performance reporting, as well as reward and punishment mechanisms $^{8}$.

Recently, demands for the accountability of public institutions, both at central and local levels, have been growing in Indonesia. Accountability can be interpreted as an obligation to account for the success or failure of the mission of an organization in achieving the goals and objectives that have been set previously and periodically ${ }^{9}$. Performance reporting is a form of transparency requirement that is a prerequisite to support government openness in its management of public resources ${ }^{7}$.

In Indonesia, one form of administrative accountability of local governments emerged with the issuance of a government decree regarding local government performance reporting (LPPD) ${ }^{10}$. LPPD can be used as one of the main sources of performance evaluation of local government as part of fulfilling transparency and accountability obligations to the public. LPPD is also positioned to be able to provide a framework for the implementation of decentralized governance. After receiving LPPD from local governments, the Indonesia Ministry of Internal Affairs will evaluate their performance by giving scores for local government performance (EKPPD).

\section{Hypothesis Development}

\section{Organizational Commitment}

Follow-up on the audit recommendations issued by the Supreme Audit Agency (BPK) and the total number of audit findings issued affect audit opinion ${ }^{11}$. Performance of follow-up audits and a decrease in the number of audit findings show the commitment of local governments to improve accountability. Commitment to implement recommendations made by the BPK is also expected to improve the performance of local government. The BPK gives recommendations based on findings of internal-control weaknesses and non-compliance with regulations. Performance improvement of local government can be achieved if local government follows up on audit recommendations from the BPK, especially those related to the improvement of internal controls. Another study has found that audit findings negatively affect local government performance ${ }^{3}$. The growing number of violations committed by local governments illustrates their increasingly poor performance. This implies that local governments can improve their performance by reducing the number of audit findings from year to year. Based on the above arguments, the first hypotheses in this study are as follows:

H1a: Follow-up of audit recommendation (TLHP) has a positive effect on local government performance.

H1b: Number of audit findings has a negative effect on local government performance.

\section{Management Incentive}

Intergovernmental revenue is revenue given by central government to local governments to be used to finance public services. The central government monitors both what is being done and the disclosure of intergovernmental revenue allocation by local governments, thus providing motivation to local governments to increase their performance. It is suggested that the higher the dependence on central government, the greater the incentives for local governments to provide better services to the public. Local governments' dependence on central government has a positive effect on the financial performance of local government districts/cities in Indonesia ${ }^{2,3}$. Public service can be improved via the allocation of non-routine expenditure such as capital expenditure, spending on goods and services, and social assistance spending. The proportion of non-routine expenditure allocation is expected to improve the performance of local government. Based on the above arguments, the second hypotheses in this study are as follows:

H2a: Intergovernmental revenue has a positive effect on local government performance.

H2b: The proportion of non-routine expenditure has a positive effect on local government performance.

\section{Monitoring}

A high level of political competition will reduce the ability of politicians to engage in opportunistic behavior that degrades their political performance. Political competition positively affects voluntary disclosure on the internet by local administrative agencies ${ }^{12}$. When the level of political competition is low the government is likely to be a monopolist, to provide fewer public services, and to gain greater benefits. Thus, the higher the level of political competition, the lower the level of opportunistic behavior, thus inducing better delivery of public services $^{13}$. Parliaments in districts/cities (DPRD) are the representations of the local electorate that serve as elements of local government administration. DPRD perform oversight functions to supervise the implementation of regulations and monitor implementation of budget revenue and expenditure. This oversight is aimed at 
monitoring proper utilization of local government budgets. Members of DPRD are directly elected, and the direct election mechanism implies that it is the people's representation in the formal decision-making structures operated by local government. DPRD members have monitoring functions and, based on agency theory ${ }^{6}$, can be considered as equivalent to a board in a corporate governance mechanism. Legislative oversight is measured in terms of the number of legislature members and is found to have a positive effect on local government performance ${ }^{4}$. The higher the number of members of the legislature, the easier it is for it to carry out oversight functions of financial management ${ }^{5}$. The larger the legislature, the greater the contribution of ideas and solutions to problems and to making decisions for the improvement of local governance. Based on the above arguments, the third hypotheses in this study are as follows:

H3a: Political competition has a positive effect on local government performance.

H3b: Legislature size has a positive effect on local government performance.

\section{Legitimacy}

The legitimacy of the heads of local governments will affect how local governments report their performance to the public. Higher levels of legitimacy will encourage local governments to provide greater accountability to the public. Legitimacy is demonstrated by public support in choosing the head of the local government through direct elections. The legitimacy of the organization will be weakened if the public's expectations of the organization's performance are not in accordance with actual performance. In contrast, legitimacy would lead a government to optimize the performance of its functions with full support from voters. Local governments that acquire strong legitimacy from their constituents tend to display better accountability to them. Based on the above arguments, the fourth hypothesis in this study is as follows:

H4: The legitimacy of the head of local government has a positive effect on local government performance.

\section{Institutional Incentives}

The main objective of local government programs is to provide good public services. Therefore, local governments need sufficient resources and adequate facilities to provide these effective public services. Larger local government areas are characterized by higher levels of assets, and thus are expected to deliver better performance. The size of local government has a positive effect on the financial performance of districts/cities in Indonesia. As well as size, own-source revenue (PAD) is also a supporting factor for macroeconomic performance ${ }^{2}$. Positive growth encourages investment and will simultaneously drive the improvement of infrastructure. Good infrastructure and high investment will increase the own-source revenue (PAD) of the local government. The increase in PAD should be supported by improved quality of public services; and quality of public services will better reflect local government performance ${ }^{2}$. Based on the above arguments, the fifth hypotheses in this study are as follows:

H5a: Size of local government has a positive effect on local government performance.

H5b: Wealth of local government has a positive effect on local government performance.

\section{RESEARCH METHODS}

\section{Data}

The population in this study consists of all local government districts/cities in Indonesia from 2009 to 2012. Purposive sampling was used to select the sample. The data was obtained from the BPK, Ministry of Internal Affairs, Central Bureau of Statistics, and local government official websites.

\section{Model}

The empirical model developed to answer the hypotheses is as follows:

EKPPD $_{\text {it }}=\mathrm{a}_{0}+\mathrm{a}_{1}$ TLHP_NOM $_{\mathrm{it}}+\mathrm{a}_{2}$ FINDINGS $_{\mathrm{it}}+\mathrm{a}_{3}$ DEPEND $_{\mathrm{it}}+\mathrm{a}_{4}$ NR_EXP $_{\mathrm{it}}+\mathrm{a}_{5}$ STROPP $_{\mathrm{it}}+\mathrm{a}_{6}$ DPRD $_{\mathrm{it}}+\mathrm{a}_{7}$ LEG $_{\mathrm{it}}$ $+\mathrm{a}_{8} \mathrm{SIZE}_{\mathrm{it}}+\mathrm{a}_{9} \mathrm{WEALTH}_{\mathrm{it}}+\mathrm{a}_{10} \mathrm{TYPE}_{\mathrm{it}}+\mathrm{a}_{11} \mathrm{EKPPD}_{\mathrm{it}-1}+€_{\mathrm{it}}$

\section{RESULTS AND DISCUSSION \\ Descriptive statistics}

Descriptive statistics for the variables are presented in Table 2. The average EKPPD score of 2.37 indicates that the average performance of the districts/cities is high (the 'high' score ranging from 2 to 3). In further considering the EKPPD score, an upward trend in local government performance from 2009 to 2011 can be seen, followed by a decline in 2012, although still classified in the high category. 
Table.2. Descriptive Statistics

\begin{tabular}{lrrrr}
\hline Variable & Mean & Std. Dev & Min & \multicolumn{1}{c}{ Max } \\
\hline Ekppd & 2.37 & 0.50 & 0.17 & 3.48 \\
tlrhp_nom & 0.36 & 0.36 & 0.00 & 1.00 \\
findings & 23.59 & 10.34 & 0.00 & 130.00 \\
Depend & 0.90 & 0.08 & 0.00 & 1.12 \\
nr_exp & 0.45 & 0.18 & 0.04 & 1.25 \\
Stropp & 0.67 & 0.20 & 0.00 & 1.00 \\
Dprd & 33.72 & 10.24 & 19.00 & 55.00 \\
Leg & 0.48 & 0.12 & 0.30 & 0.95 \\
Lsize & 12.16 & 0.35 & 9.73 & 14.48 \\
Wealth & 0.04 & 0.03 & 0.00 & 0.38 \\
Typle & 0.19 & 0.39 & 0.00 & 1.00 \\
Lekppd & 2.41 & 0.41 & 0.28 & 3.48 \\
\hline
\end{tabular}

\section{Hypothesis Testing}

The empirical results for the hypothesis testing are presented in Table 3. They show that organizational commitment, as measured in terms of follow-up of audit recommendations from the BPK (H1a), has a positive effect on local government performance. Recommendations that are followed up by local governments consist of following up on internal-control improvements and compliance with regulations that can increase the effectiveness of local government performance. In relation to the number of audit findings indicator (H1b), this study confirms that the higher the number of audit findings, the worse ${ }^{3}$ local government performance is. Local governments should commit to complying with all audit recommendations from the BPK to achieve better performance. Follow-up of audit recommendations can be focused on findings relating to waste of money, inefficiency, and ineffectiveness, since those findings are closely associated with improved performance.

Tabel.3. Hypothesis Testing

\begin{tabular}{lccrrl}
\hline \multicolumn{1}{c}{ Variable } & Hyp & $\begin{array}{c}\text { Exp. } \\
\text { Sign }\end{array}$ & Coef & P>t & Sig \\
\hline Cons & & & -0.04 & 0.49 & \\
tlrhp_nom & H1a & + & 0.18 & 0.00 & $* * *$ \\
findings & H1b & - & -0.01 & 0.00 & $* * *$ \\
depend & H2a & + & 0.55 & 0.04 & $* *$ \\
nr_exp & H2b & + & 0.22 & 0.06 & $*$ \\
Stropp & H3a & + & -0.07 & 0.25 & \\
Dprd & H3b & + & 0.01 & 0.00 & $* * *$ \\
Leg & H4 & + & 0.31 & 0.04 & $* *$ \\
lsize & H5a & + & 0.02 & 0.42 & \\
wealth & H5b & + & 1.67 & 0.03 & $* *$ \\
type & & & 0.10 & 0.05 & $* *$ \\
lekppd & & & 0.46 & 0.00 & $* * *$ \\
Number of observation & & & 457.00 & \\
Adjusted R-square & & & $37.88 \%$ & \\
\hline
\end{tabular}

Notes: EKPPD = EKPPD score; TLHP_NOM = nominal value of recommendations completely followed up plus recommendation that cannot be followed up divided by the total nominal value of recommendations; FINDINGS = number of audit findings; DEPEND = total transfer revenue divided by total revenue; NR_EXP = total non-routine expenditure (expenditure other than employee expenditure) divided by total expenditure; STROPP = legislature members from opposition parties to local government head divided by total number of legislature members; DPRD = number of legislature members; LEG = number of voters from direct election; WEALTH = total own-source revenue divided by total revenue; TYPE = dummy variable: 1 if districts; 0 if others; LEKPPD = EKPPD score previous year.

The dependency of local governments on central government as measured by intergovernmental revenue (H2a) has a positive effect on local government performance ${ }^{2,3}$. Data from the descriptive statistics shows that the average transfer income to total revenue is $90 \%$. Large amounts of transfer income will encourage management to comply with the rules established by central government, including allocating funds to improve public services and the welfare of the community. The proportion of non-routine expenditure (H2b) also has a positive effect on 
performance. The average proportion of non-routine expenditure based on the data is $45.3 \%$. Local governments should focus on the level of non-routine expenditure to improve public services infrastructure and poverty alleviation, such as higher allocation for education spending and entrepreneurship.

The effect of political competition on performance (H3a) is not supported, while the number of legislature members (H3b) has a positive effect on local government performance. This result implies that the oversight is done collectively by the all legislature members and does not depend on whether they are from a coalition or a party in opposition to the local government head. This further confirms that parliament has been functioning properly in overseeing local government functions. The strategic role of the local parliament is to approve the budget and monitor implementation. Local parliament, as the voters' representation, will pay attention to budget allocation to be utilized to improve the performance of local government in providing public services. This study shows that the number of legislature members has a positive effect on local government performance. They can share ideas and give optimum contributions and solutions to solve problems and make decisions to establish better local governance.

Legitimacy, as measured by the number of votes in the local government general election (H4), has a positive effect on local government performance. Descriptive statistics data in Table 2 show that the average number of votes for local government heads of districts/cities amounted to $48 \%$. These data indicate a high degree of legitimacy for local government heads. Higher levels of legitimacy will encourage local governments to provide greater public accountability. Legitimacy would encourage local governments to optimally perform their functions because they have received full support from voters and because they can use their legitimacy to gain/keep/regain votes in upcoming elections.

The size of local governments (H5a) does not affect their performance, while the level of local government wealth (H5b) has a positive effect on performance. These results indicate that the funds generated from local governments' own sources will encourage local governments to give back to society in the form of improved services and increased wealth ${ }^{2,3}$.

\section{CONCLUSION}

The purpose of this study is to analyze the determinants of local government performance in Indonesia. The determinants tested are organizational commitment, management incentives, monitoring, legitimacy, and institutional incentives. Organizational commitment is measured by follow-up of all audit recommendations and the number of audit findings, while intergovernmental revenue and proportion of non-routine expenditure is used to measure management incentives. Monitoring is measured by political competition and legislature size. Number of voters is used to measure size, while size and wealth of local government proxy for institutional incentives. Districts/cities in Indonesia from 2009-2012 are used as the sample. The test results show that follow-up of audit recommendations, level of dependency on central government, proportion of non-routine expenditure, number of legislature members, number of voters and local government wealth have positive effects on local government performance.

An important implication of this study is that local governments should increase their commitment to decreasing the number of BPK audit findings, and to following up all the audit recommendations made to them. They should also increase non-routine expenditure and own-source revenue in order to improve their performance. In formulating the EKPPD score, central government should put more emphasis on activities that are directly related to the improvement of public welfare and public services in their measurement of performance. Legislative boards can support local governments to increase performance by performing their monitoring role effectively.

Some limitations and suggestions for further research include: (1) organizational commitment should not only be measured using the number of audit findings, but also with reference to the decrease in the number of audit findings. In addition, the findings may also be broken down into those relating to performance, such as waste of money, inefficiency, and ineffectiveness; (2) legislative oversight should be measured using a more comprehensive measure, not only considering the number of board members, but also the background and activities of board members in conducting oversight. Future studies may consider public supervision such as press monitoring; (3) legitimacy can also consider the incumbent versus non-incumbent balance, because if there is a chance of reelection then there is an urgency to show better performance.

\section{REFERENCES}

[1] Ghobadian, Abby, and John Ashworth. Performance measurement in local government-concept and practice, International Journal of Operations \& Production Management, 14.5 (1994) 35-51.

[2] H. Sumarjo. The effect of local government characteristics on local government financial performance, Dissertation (Unpublished), UNS, (2010).

[3] W. A. Mustikasari. The effect of local government characteristics and BPK findings on local government (disctricts/cities) in Indonesia year 2007, Undergraduate Thesis (Unpublished), Universitas Indonesia, (2012).

[4] H. A. Saragih. The effect of functional and legislative monitoring on local government performance in Indonesia year 2011-2012, 
Undergraduate Thesis (Unpublished), Universitas Indonesia, (2015).

[5] M. Kusumawardani. The effect of size, wealth, legislative size, leverage on local government financial performance in Indonesia, Accounting Analysis Journal 1, Universitas Negeri Semarang, (2012).

[6] Sutaryo and J. Winarna. Legislative characteristics and local government performance: empirical support from agency theory perspective, Simposium Nasional Akuntansi XVI, Manado (2013).

[7] Mardiasmo. Public sector accounting, Andi Publishing, Yogyakarta (2002).

[8] Ormond, Derry, and E. Loffler. New public management: what to take and what to leave. Proceedings of III International Conference of CLAD on State and Public Administration Reform, Madrid, Spain (1998).

[9] W. T. Stanbury. Accountability to citizens in the Westminster model of government: more myth than reality, Fraser Institute, (2003).

[10] Republic of Indonesia. Government Decree Nomor 3 Tahun 2007 about Local Government Performance Report. Sekretariat Negara. Jakarta

[11] D. Setyaningrum. Auditor quality, legislative oversight and the usefulness of audit results towards local government financial accountability, Dissertation (Unpublished), Universitas Indonesia (2015).

[12] Serrano-Cinca, Carlos, Mar Rueda-Tomás, and Pilar Portillo-Tarragona. Factors influencing e-disclosure in local public administrations, Environment and planning C: Government and Policy, 27.2 (2009) 355-378.

[13] Lake, David A., and Matthew A. Baum. The invisible hand of democracy: political control and the provision of public services, Comparative political studies, 34.6 (2001) 587-621. 